\title{
SANTA TERESA DE JESÚS, FUNDADORA DE UNA FAMILIA RELIGIOSA
}

DOI: https://doi.org/10.52039/seminarios.v61i214.176

LUIS JAVIER FERNÁNDEZ FRONTELA*

A veces conviene repetir, para no olvidarlo -y más cuando ciertas lecturas presentistas imaginan a Teresa de Jesús viviendo en nuestro tiempo con otra dirección distinta a la que ella vivió en el lejano siglo XVI-, que Teresa fue una persona entregada de por vida a la oración y al recogimiento. Ella «encontró su vocación al encontrarse a sí misma como alma y maestra de oración» ${ }^{1}$. Y esto es lo que va a llevar a cabo en su periplo fundacional, que abarca los veinte últimos años de su vida, desde 1562 hasta 1582: crear comunidades donde las monjas se dediquen a la oración en servicio a la Iglesia. Teresa está convencida de que «todas las que traemos este hábito sagrado del Carmen somos llamadas a la oración y contemplación».

\section{TIEMPO DE REFORMA}

La Madre Teresa vive en el siglo XVI, entre 1515 y 1582, tiempo en que la Iglesia es sacudida hasta sus cimientos por el movimiento protestante con sus diferentes reformas, de ahí que ella denomine al tiempo que le toca vivir como «tiempos recios» ${ }^{2}$. A la Madre Teresa le tocó vivir aquel mundo y aquellos tiempos en los que se asiste a la ruptura de la unidad de la Iglesia, la cual ella vive de forma dolorosa. Si en 1483, año en que viene al mundo Martín Lutero, toda Europa es católica y obediente al Papa de Roma, el año 1546, año de la muerte de Lutero, casi la mitad de Europa se ha separado de Roma. Hacia 1562 le llega a Teresa la noticia del poder creciente de los protestantes en Francia, y de cómo

* Carmelita descalzo, licenciado en teología e historia, director del Centro de Estudios Josefinos en Valladolid y de la Revista de Estudios Josefinos. Es también colaborador de la Revista de Espiritualidad y de la Revista Teresa de Jesús. De esta última fue además director durante cerca de veinte años. También ha sido profesor de Historia de la Iglesia en la Facultad de Teología de San Esteban, en Salamanca. Ha publicado múltiples artículos en todas estas revistas y participado en obras en colaboración.

1. Segundo Fernández, Espíritu teresiano de oración: El Adelanto, suplemento extraordinario del Año Santo Teresiano, Salamanca, 24 de agosto 1962.

2. Santa Teresa, Libro de la Vida 35, 5 (en adelante, Vida; citamos por Obras completas, Madrid $\left.{ }^{5} 2000\right)$. 
para ellos no hay sacramento de la eucaristía, ni sacerdocio, y cómo deshacen la unidad de la Iglesia. Teresa, como ella misma nos dice, rompe a llorar: «En este tiempo vinieron a mi noticia los daños de Francia y el estrago que habían hecho estos luteranos, y cuánto iba en crecimiento esta desventurada secta. Diome gran fatiga, y como si yo pudiera algo o fuera algo, lloraba con el Señor, y le suplicaba remediase tanto mal» (Camino de Perfección de Valladolid 1, 2; en adelante, Camino). Teresa no distingue entre luteranos y calvinistas -los de Francia de los que ella habla no eran luteranos, sino calvinistas- ni conocía sus doctrinas, ni las razones por las que rechazaban a la Iglesia católica. Ella piensa lo que ha oído a sus confesores dominicos y jesuitas que «estase ardiendo el mundo, quieren tornar a sentenciar a Cristo, pues le levantan mil testimonios, quieren poner su Iglesia por el suelo» (Camino 1, 5). A Teresa esta situación le da pena y dolor: «La grandísima pena que me da las muchas almas que se condenan; de estos luteranos en especial, porque eran ya por el Bautismo miembros de la Iglesia» (Vida 32, 6). A ella le duele que la Iglesia esté rota, lo que le mueve a buscar un remedio.

Fueron tiempos de una gran ansia de reforma en la vida cristiana en todas sus esferas, reformas de las estructuras y conversión de las personas, de búsqueda del camino de la verdad. Desde finales del siglo XV y a lo largo del siglo XVI se siente la necesidad y el deseo vivo de Dios, experimentado al margen incluso de las mediaciones humanas, un deseo de alcanzar la salvación. Se busca una vida cristiana entendida como experiencia del Dios misterioso que, existiendo desde siempre, se ha hecho rostro y palabra humana, libro vivo, en expresión de Teresa, en Jesucristo. Ella gustaba, como otros muchos auténticos cristianos de su tiempo de una u otra confesión, leer y meditar los textos de la Sagrada Escritura, que para ella es la palabra de Dios, y por eso recomienda que la oración debe fundamentarse en la meditación del evangelio, en las palabras y en los hechos de la vida del mismo Cristo, porque la oración consiste en traer a la memoria al Dios amigo.

Por todas partes se busca una vida cristiana liberada del estrecho corsé al que se veía sometida por toda una serie de mediaciones externas que asfixiaban al cristianismo y que hacían olvidar que la fe es un acto de confianza radical en la palabra de Dios, el Dios encarnado, el Dios de la misericordia, que «no se espanta de las flaquezas de los hombres, que entiende nuestra miserable compostura» (Vida 37, 6). Hasta entonces dominaba una experiencia religiosa entendida como acto de obediencia ciega a la autoridad, a la tradición, al rito, a los medios, como temor -no siempre reverencial- a Dios, lo que lleva a vivir en una actitud de angustia ante la salvación. Como contraposición se busca una experiencia religiosa entendida como amistad-confianza- en el Dios manifestado en Jesucristo, que para Teresa es un Dios amigo.

En el siglo XVI, aunque el proceso viene de antes, encontramos un contexto de reforma de la vida religiosa, si bien por otra parte asistimos, sobre todo en el 
mundo masculino, al nacimiento de nuevas formas de vida religiosa, como es el caso de los jesuitas -los clérigos regulares-. El término reforma no tiene en estos momentos el significado que se le había dado en la Edad Media, de recuperación de la primitiva forma evangélica de vida, sino que se refiere al reajuste de la disciplina, insistiendo en el silencio, la austeridad, la reclusión, la vuelta al derecho común, la renuncia a los privilegios, la corrección de abusos. Las reformas, pues, van a insistir ante todo en los aspectos disciplinares.

Teresa, en medio de ese ambiente de reforma, desea remediar este gran mal de la división de la Iglesia. Se da cuenta de que no bastan los ejércitos del rey para impedir que se extienda la división: "Se ha pretendido hacer gente, para si pudieran a fuerza de armas remediar tan gran mal y que va tan adelante» (Camino 3, 1). Propone entonces que cada uno haga lo poco que pueda; ella y sus monjas procurarán «ser tales que valgan nuestras oraciones para ayudar a estos siervos de Dios, que con tanto trabajo se han fortalecido con letras y buena vida y trabajos para ayudar ahora al Señor» (Camino 3, 2). María de San Francisco afirma, al declarar en el proceso de Beatificación de la Madre: «Solía decir muchas veces la dicha Madre, Teresa de Jesús, que el fin que había tenido en renovar esta Religión habían sido las herejías... que se habían levantado contra la fe católica; y para que hubiese personas que de día y de noche estuviesen encomendando a nuestro Señor la defensa de su Santa Iglesia, que, pues había enemigos públicos contra ella, hubiese personas que secretamente estuviesen siempre encomendando a Dios, y así fundó en su vida quince conventos de monjas de la dicha orden y otros conventos de religiosos varones» ${ }^{3}$.

Por la reforma de la vida religiosa, y también de la Iglesia, claman todos los sectores: los papas, los obispos, los reyes, los predicadores, los autores ascéticos. En medio de este ambiente, la Reforma Teresiana se distingue de las otras reformas -las llevadas a cabo por el Papa, por el Rey... todos están interesados en reformar la vida religiosa- en que no es una reforma impuesta desde arriba a comunidades supuestamente relajadas. La Madre Teresa no parte de que el monasterio de la Encarnación, con todos los convenientes e inconvenientes que en él encuentra, estuviese relajado. No se trata de volver simplemente a la Regla primera sin mitigación, aunque también, sino de hacer algo nuevo. La Madre Teresa crea comunidades de nueva planta, no busca reformar comunidades ya hechas, y las crea con una orientación específica.

No vamos a detenernos en viejas polémicas entre el carisma del reformador y el carisma del fundador. En todo movimiento reformador se da un regreso a la Regla sin comentarios, sin glosa, un regreso al espíritu primitivo. Por el contrario, en un movimiento fundador, al margen de mirar o no al pasado, a los orígenes -que en la Madre Teresa se dio, al querer conservar la continuidad del Carmelo:

3. Declaración de María de San Francisco, en Silverio de Santa Teresa, Procesos de beatificación y canonización de Santa Teresa II, Monte Carmelo, Burgos 1935, 62. 
«Pongan siempre los ojos en la casta de donde venimos, de aquellos santos profetas. ¡Qué de santos tenemos en el cielo que trajeron este hábito! Tomemos una santa presunción, con el favor de Dios, de ser nosotros como ellos»-, se trata de «hacer algo nuevo» (Fundaciones 29, 33). Lo novedoso en la Madre Teresa, no es el pasado en sí, sino el avance hacia delante, lo que nos lleva a pensar que «quiso que naciese un nuevo estilo de vida religiosa», y lo hace siempre en fidelidad a la Iglesia.

\section{EL CONCEPTO DE VIDA RELIGIOSA EN LA MADRE TERESA}

Para la Madre Teresa la vida religiosa es un determinarse por Dios, un dejarlo todo por él. Sin esa «determinación» ella no habría atravesado los umbrales de La Encarnación cuando, a los veinte años de edad, se decidió a ser monja. Debemos tener presente que Teresa fue monja por propia decisión, algo no demasiado habitual entonces, y también que Teresa no siempre quiso ser monja. Hubo un momento en que la vida en el claustro no entraba en el horizonte de sus proyectos, y ello a pesar de que en su infancia había soñado con que la descabezasen y comprar barato el cielo, y había jugado a ser ermitaña y a tener vida de silencio y a construir monasterios, donde ella era la priora. Pero todo eso, aunque muy marcado en el recuerdo de Teresa, no era sino sueños de infancia. En su adolescencia, la lectura de libros de caballería y el gusto que tenía por agradar la convierten en «enemiguísima de ser monja» (Vida 8, 2).

Fue en el Monasterio de Santa María de Gracia, de monjas Agustinas, donde la había internado su padre, y por influjo de su tutora María de Briceño -monja inteligente y fervorosa, de unos veintiocho años de edad, de porte distinguido y carácter bondadoso y comprensivo- donde comienza a tener «amistad de ser monja». María de Briceño dejó huella en Teresa, como ella misma cuenta: «Comenzome a contar cómo ella había venido a ser monja por sólo leer lo que dice el Evangelio: Muchos son los Ilamados y pocos los escogidos» (Vida 3, 1). Estas palabras marcan el despertar de su vocación futura, pero aún tenía que vencer otras resistencias: «Estuve año y medio en este monasterio harto mejorada. Comencé a rezar muchas oraciones... para que Dios me diese el estado en que le había de servir; mas todavía deseaba no fuese monja, que éste no fuese Dios servido de dármele, aunque también temía el casarme... A cabo de este tiempo que estuve aquí ya tenía más amistad de ser monja» (Vida 3, 2).

Una cosa llama la atención en Teresa, ya desde su infancia: la fuerza que tiene en ella la imaginación. Esto deriva de la afición a la lectura que había en su casa, inculcada por sus padres. Si lee o escucha la lectura del Flos Sanctorum, las vidas de los santos, desea ser mártir y descabezada por los moros. Si acude a la recreación de libros de caballerías, solamente repara en su cuidado personal: manos, cabellos, perfumes. Al conversar con la monja María de Briceño, pasa de sentirse enemiguísima de ser monja a desear tal estado para ella. 
En 1533, se pone en camino a Hortigosa de paso a Castellanos de la Cañada, pequeña alquería de unos diez vecinos, donde vivía su hermana María, para descansar y reponerse de una enfermedad. Cambio de clima y paisaje, de la ciudad a la aldea: «Diome una gran enfermedad, que hube de tornar en casa de mi padre. En estando buena, lleváronme en casa de mi hermana, que residía en una aldea, para verla, que era extremo el amor que me tenía» (Vida 3, 3). En Hortigosa visita a su tío Pedro, el único de los tíos que nombra en el Libro de la Vida: "Un hermano de mi padre, muy avisado y de grandes virtudes, viudo, a quien también andaba el Señor disponiendo para Sí, que en su mayor edad dejó todo lo que tenía y fue de suerte que creo goza de Dios. Quiso me estuviese con él unos días. Su ejercicio eran buenos libros de romance y su hablar era -lo más ordinario- de Dios y de la vanidad del mundo. Hacíame leyese y, aunque no era amiga de ellos, mostraba que sí, porque en esto de dar contento a otros he tenido extremo, aunque a mí me hiciese pesar, tanto que en otras fuera virtud y en mí falta, porque iba muchas veces muy sin discreción».

Teresa, en los días que pasa en Hortigosa, donde los fríos del otoño-invierno de la sierra abulense no dejan hacer mucho, lee libros de devoción, entre ellos las Epístolas de San Jerónimo. Fue aquí, en Hortigosa, sin que ella se apercibiese, y gracias a las lecturas y a los consejos de su tío don Pedro, donde Teresa emprende el camino de los buenos libros y con ellos da los primeros pasos hacia el que va a ser «camino del alma», la oración: «Aunque no acababa mi voluntad de inclinarse a ser monja, vi era el mejor y más seguro estado; y así poco a poco me determiné a forzarme para tomarle» (Vida 4, 5).

Teresa vuelve de este viaje por la sierra abulense con el deseo de ser monja. Entre este invierno de 1533 y el otoño de 1535, cuando ingresa en el monasterio de la Encarnación, Teresa se trae un tira y afloja con su padre. Ella quiere ser monja, pero don Alonso no está dispuesto a autorizárselo. Debemos comprender al viejo don Alonso, pues Teresa es su hija más querida. Don Alonso, viudo desde hace años, ve que se está quedando solo: sus hijos varones, buscando fortuna, parten a las Indias, la hija mayor se ha casado y vive en una aldea de la sierra abulense, en casa quedan Teresa -que hace de ama de casa- y la pequeña Juana. Don Alonso no está dispuesto a que su hija se vaya al convento, al menos en sus días: «En ninguna manera lo pude acabar con él, ni bastaron ruegos de personas que procuré le hablasen. Lo que más se pudo acabar con él fue que, después de sus días, haría lo que quisiese». Pero Teresa, que se ha determinado a «dejarlo todo», en este momento no teme dejar solo a su padre y meterse monja en la Encarnación. Ella misma dice que «era tan honrosa que me parece no tornara atrás por ninguna manera, habiéndolo dicho una vez» (Vida 3,7 ).

La joven Teresa llega a la conclusión de que ser monja «era mejor y más seguro estado», pero también la forma de alcanzar o ganar el sueño de la infancia, el cielo: "Los trabajos y pena de ser monja no podían ser mayor que la del purgatorio, y después me iría derecha al cielo, que éste era mi deseo» (Vida 3, 5-6). 
No la mueve aún el amor a la persona de Cristo, a Dios, sino el temor ¿Temor a qué?, a perder el cielo, a no ganar la salvación, que es la gran riqueza que todos en aquella sociedad del siglo XVI quieren alcanzar.

En 1535, cuando Teresa cuenta veinte años, el día de ánimas, se fuga de casa «muy de mañana». Escribe: «Acuérdaseme, a todo mi parecer y con verdad, que cuando salí de casa de mi padre no creo será más el sentimiento cuando me muera. Porque me parece cada hueso se me apartaba por sí, que, como no había amor de Dios que quitase el amor del padre y parientes, era todo haciéndose una fuerza tan grande que, si el Señor no me ayudara, no bastaran mis consideraciones para ir adelante. Aquí me dio ánimo contra mí de manera que lo puse por obra» (Vida 4, 1).

Y cuando asoma la tentación del desaliento ante las dificultades y trabajos que la vida religiosa acarreaban - «poníame el demonio que no podría sufrir los trabajos de la religión, por ser [yo] tan regalada»-, su pensamiento la lleva a Cristo: «Esto me defendía con los trabajos que pasó Cristo, porque no sea mucho yo pasase algunos por él» (Vida 3, 6).

\section{EL PROYECTO TERESIANO}

La idea de fundar un nuevo convento, una forma nueva de comunidad, nació en una conversación que tuvo Teresa en su celda de la Encarnación con otras monjas del mismo monasterio (Vida 32, 10-11). Una de ellas, María de Ocampo, propuso hacer un convento a «manera de Descalzas». Este proyecto se concreta en establecer una vida de familia en la que todo fuese pobre, «no sólo en comer y vestir, sino también en los edificios en que fuesen muy humildes, nada curiosos y poco costosos... porque las pobres en todo lo habían de ser y holgarse de parecer» ${ }^{4}$.

Cuando Teresa de Ahumada salió de la Encarnación en 1562, no pasaba por su imaginación que un día se convertiría en fundadora de una nueva familia religiosa. No fundó el convento de San José con pretensiones de seguir fundando después otros más hasta donde llegaran sus fuerzas. Su idea fue, ni más ni menos, la de «hacer un monesterio adonde ha de haber solas quince, sin poder crecer el número, con grandísimo encerramiento, ansí de salir como de no ver si no han velo delante del rostro, fundadas en oración y en mortificación $»^{5}$. En las primeras páginas del libro de las Fundaciones, la Madre Teresa presenta el proyecto inicial de San José, pensado como una casa de rigor, a manera de descalzas, para diferenciarse de la Encarnación. De ahí la importancia que da a la clausura, a vivir el mayor encerramiento para buscar una mayor perfección, al número reducido de monjas, a la pobreza radical inspirada en la «Regla primiti-

4. Declaración de Isabel de San Pablo, en Silverio de Santa Teresa, Proceso, 88-89.

5. Carta a Lorenzo de Cepeda (Quito, Ecuador), Ávila, 23 de diciembre de 1561. 
va» de la orden y a la vida de oración. San José nace como una comunidad de mujeres orantes. En principio, la Madre Teresa no pensaba en más monasterios. En este sentido podemos decir que San José mira hacia atrás, hacia los orígenes de la orden del Carmen, a «aquellos santos padres nuestros del Monte Carmelo que en tan gran soledad y con tanto desprecio del mundo buscaban este tesoro, esta preciosa margarita de que hablamos».

En los años que siguen a la fundación de San José, 1562-1567, «los más descansados de mi vida, cuyo sosiego y quietud echa harto menos muchas veces mi alma» (Fundaciones 1, 1), aflorarán los elementos de modernidad del proyecto teresiano al descubrir el sentido eclesial de la vida consagrada, que se traducirá en la preocupación por la salvación de las muchas almas que se pierden en los nuevos territorios de Indias -el ideal misionero-, nacida en ella a partir de la visita del franciscano fray Alonso Maldonado. Y en segundo lugar, la preocupación por la Iglesia, por su unidad, ante la ruptura de la misma por el movimiento protestante, lo que supone la desaparición de la vieja cristiandad medieval. A partir de este momento no basta ya con el mayor encerramiento para buscar una mayor perfección, la salvación, sino que es necesario poner la comunidad orante al servicio de la Iglesia.

El ideal inicial de la Madre Teresa se perfila en estos años de quietud en San José hasta concretarse en cuatro puntos: formar un pequeño grupo selecto, donde ser buenos cristianos, viviendo el ideal del evangelio, teniendo por ocupación principal la contemplación, la oración, a la que da un sentido apostólico, imprimiendo un sentido eclesial a la propia vocación.

La idea de fundar nuevos monasterios al estilo del de San José no fue original de la Santa, sino del P. Juan Bautista Rubeo, general de la Orden del Carmen. Cuenta la Madre que habiendo venido Rubeo a España, y llegado a Ávila, procuró que fuese a su convento de San José -donde no se consideraba del todo segura-y allí le dio cuenta de lo ocurrido "y casi de toda mi vida, aunque es harto ruin. Él me consoló mucho, y aseguró que no me mandaría salir de allí. Alegrose de ver la manera de vivir, y un retrato, aunque imperfecto, del principio de nuestra Orden, y cómo la regla primera se guardaba en todo rigor, porque en toda la Orden no se guardaba en ningún monasterio, sino la mitigada, y con la voluntad que tenía de que fuese muy adelante este principio, diome muy cumplidas patentes, para que se hiciesen más monasterios, con censuras para que ningún provincial me pudiere ir a la mano. Estas yo no se las pedí, puesto que entendió de mi manera de proceder en la oración, que eran los deseos grandes de ser parte para que algún alma se llegase más a Dios. Estos medios yo no los procuraba, antes me parecía desatino, porque una mujercilla tan sin poder como yo, bien entendía que no podía hacer nada; mas cuando al alma vienen estos deseos, no es en su mano desecharlos. El amor de contentar a Dios y la fe hacen posible lo que por razón natural no lo es; y así en viendo yo la gran voluntad de nuestro reverendísimo general para que hiciese más monasterios, me pareció los veía hechos. 
Acordándome de las palabras que Nuestro Señor me había dicho, veía ya algún principio de lo que antes no podía entender» (Fundaciones 3, 1-4). Ocurrió esto a los cuatro años de la fundación de San José, de Ávila.

En este sentido, el Libro de las Fundaciones, continuación de la narración de la fundación del monasterio de San José de Ávila, primera de las fundaciones llevadas a cabo por la Madre Teresa, insertada en los últimos capítulos del Libro de la Vida (Vida 33-36), viene a ser como la crónica del nacimiento de una nueva familia religiosa. En Fundaciones encontramos el relato de la fundación y la expansión de los monasterios de monjas, el nacimiento de los frailes con la fundación de Duruelo (Fundaciones 14) y la fundación de los Descalzos de Pastrana (Fundaciones 17), el enfrentamiento con los Calzados y la consecución de provincia independiente.

\section{LA MADRE TERESA, FUNDADORA}

Desde los inicios del Carmelo Descalzo nunca se cuestionó que Teresa fuera la fundadora, pero no siempre se tuvo claro -al menos por algunas corrientes- que lo fuera de los frailes. El P. Jerónimo Gracián defiende el carácter de fundadora de la Madre Teresa, tanto de las monjas como de los frailes: «Qué título tuviese para esto [ser fundadora] -respondió Cirilo-y las patentes de sus Generales que así la nombran y cuántos monasterios fundó, otro día te lo dirá Eliseo, que yo ahora no puedo sufrir que se le haga agravio y niegue título de fundadora y deje de alcanzar eterno nombre quien cosas tan nuevas y tan provechosas inventó en el mundo. Porque aunque la Orden no es nueva, ni la Regla, ni todas las Constituciones, pero muchas dellas compuso esta sierva de Dios que después confirmaron los Generales; y el tocado y mucho del vestido y otras costumbres que se guardan en los monasterios, ella dio principio».

Por el contrario, el P. Ángel de San Gabriel, maestro de novicios en Pastrana, segundo de los conventos de Descalzos, amigo de rigores y prácticas alejadas del ideal teresiano, afirma que «aunque me voy tras la corriente común diciendo que la M. Teresa de Jesús es fundadora de las monjas y frailes descalzos, llévame tras sí la M. Cardona. Los frailes descalzos más tienen y mejor les está imitar a la ermitaña Cardona que a la monja Teresa. Es fuerza decillo, que no es menos fundadora de los frailes descalzos la M. Cardona que la M. Teresa de Jesús, antes más; porque del convento de Pastrana que fundaron el P. Mariano y Fr. Juan de la Miseria, se ha multiplicado la orden más que de la casa de Mancera que fundaron los dos frailes calzados que redujo a descalzos la M. Teresa. Y aquella casa de Mancera ya acabó, y así la de Pastrana es agora la primera y, por consiguiente, la matriz y medida de vida» 6 .

6. «La escisión de Pastrana», en Congreso Internacional Teresiano, 4-7 octubre 1982, Salamanca 1983, 399. 
Más allá de las polémicas, hay algo que está claro históricamente, y de ello es prueba el Libro de las Fundaciones: la misma Madre es consciente de que los conventos de descalzos, tanto de monjas como de frailes, pertenencen a una misma familia: «Están hechos a una todos estos monasterios» ${ }^{7}$.

Cuando Teresa de Jesús inicia su obra, «hacer eso poquito que yo puedo y es en mí, que es seguir los consejos evangélicos con toda la perfección que yo pudiese, y procurar estas poquitas que están aquí hiciesen lo mismo» (Camino $1,2)$, que culminará en el Carmelo Descalzo, la movieron varios motivos. Ella nos habla al menos de tres: recuperar la vida de oración y pobreza que vivieron en el Monte Carmelo (Palestina) los ermitaños que fundaron la Orden, el deseo de volver a los orígenes; rezar por la unidad de la Iglesia, dividida por la entonces reciente escisión del Protestantismo; pedir a Dios por la propagación de la fe cristiana en los inmensos territorios descubiertos en aquel siglo. Pero Teresa de Jesús, al fundar sus comunidades, aunque no lo manifiesta expresamente, crea un ámbito de libertad para las monjas de su tiempo.

La Madre Teresa diseña una forma de vida religiosa distinta a la vivida por ella en la Encarnación y caracterizada por la austeridad, donde no cabe la vanidad ni la curiosidad, comenzando por el vestido, que debían ser «de jerga o sayal negro», «la manga angosta, no más en la boca que al principio; sin pliegue, redondo, no más largo detrás que delante, y que llegue hasta los pies. Y el escapulario de lo mismo, cuatro dedos más alto que el hábito. La capa de coro de la misma jerga blanca, en igual del escapulario, y que lleve la menos jerga que ser pueda, atento siempre a lo necesario y no superfluo». Calzadas con alpargata y «por la honestidad calzas de estopa», nunca zapato. Austero el porte de la monja, comenzando por el cabello: «Han de tener cortado el cabello, por no gastar tiempo en peinarle». Ausencia de todo aquello que pueda distraer: «Jamás ha de haber espejo, ni cosa curiosa, sino todo excluido de sí». Austeridad en el convento, ella recomienda que las casas sean «pobres y chicas» (Camino 2, 9), que reúnan las condiciones necesarias para el recogimiento; en la celda, en el lecho: «Las camas sin ningún colchón, sino con jergones de paja: que probado está por personas flacas y no sanas que se puede pasar».

Una vida austera: «Vosotras, hijas, siempre mirad con lo más pobre que pudiereis pasar, así de vestidos como de manjares $»^{8}$, pero no en excesos, sobre todo en lo que se refiere al ansia de sacrificios de las monjas, algo que temía la Madre Teresa; por eso recomienda que ninguna monja «tome más (disciplina) sin licencia, ni haga cosa de penitencia sin ella». La penitencia debe estar siempre subordinada al ejercicio de las virtudes: "Yo soy amiga de apretar mucho en las virtudes, mas no en el rigor» ${ }^{9}$. La Madre Teresa quería en sus comunidades vir-

7. Carta al P. Pedro de los Ángeles, Ávila, octubre de 1578.

8. Conceptos de Amor de Dios 2, 8, 10.

9. Carta del Padre Ambrosio Mariano, 12 de diciembre de 1576, 10. 
tudes practicadas con gozo, con afabilidad y con dulzura (Camino 41, 7). Busca que reine una alegría sana y santa, que anime toda la vida de sus comunidades. No le gustaban los santos «encapotados»; escribía al Padre Gracián: «Crea que una monja descontenta yo la temo más que a muchos demonios $»^{10}$. Quería ver en sus hijas una santidad impregnada de dulzura y suavidad, de alegría y de comprensión, de disponibilidad y de afabilidad; por eso dejó escrito que, «mientras más santas, más conversables con sus hermanas» (Camino 41, 7).

Lo que Teresa buscaba era crear un convento donde vivir la mayor perfección, donde establecer una nueva forma de ver la vida religiosa y donde -estando presente el ideal de la orden, «hacer eso poquito que podemos», la oración, la contemplación- se diese gran importancia al ideal comunitario y fraterno, así como a la vertiente apostólica que ella intuye en la vida consagrada. Para ella las que habitan en sus conventos han venido a servir al Señor: "Como religiones de mujeres no son ordenadas para enseñar ni predicar, aquella será más alta que está ordenada para ayudar con sus oraciones y penitencias a los que esto hacen, que son los que defienden la Iglesia, pues aquello es más perfecto que más se llega a lo que tiene la cumbre de la perfección. Y no puede ninguna religión de mujeres tener más alto fin que orar siempre y ayunar y usar de asperezas por la conservación y defensión de la Iglesia Católica y la salud de las almas, procurando que los fieles vivan conforme a su llamamiento, y los infieles vengan a conocimiento de su Criador» ${ }^{11}$.

Para la Madre Teresa, la oración -que es el cimiento de esta casa y a esto «nos juntamos»-es el «ejercicio principal». En cuanto al tipo de oración, ella dirá que «oración mental, y quien ésta no pudiere, vocal y lección y coloquios con Dios» (Camino 18, 4), lo que supone ir contra corriente y escandalizar a algún que otro letrado, pues no pocos de ellos consideraban a la mujer incapaz de hacer oración mental: «Como muchas veces acaece con decir: hay peligros, fulana por aquí se perdió, el otro se engañó, el otro que rezaba cayó, dañan la virtud, no es para mujeres, que les vienen ilusiones, mejor será que hilen, no han menester estas delicadezas, basta el Paternóster y Avemaría» (Camino 21, 2).

La Madre Teresa, a partir de San José y a lo largo del periplo fundacional que abarca los quince últimos años de su vida, creó comunidades con una orientación orante y con fuertes relaciones interpersonales. Está convencida, por experiencia, que sin comunidad orante no se puede tener oración. Ella, que no tuvo comunidad orante en sus años de monja en la Encarnación, escribe sobre aquellos años: «Gran mal es un alma sola entre tantos peligros. Paréceme a mí que, si yo tuviera con quien tratar todo esto, que me ayudara a no tornar a caer, siquiera por vergüenza, ya que no la tenía de Dios» (Vida 1, 20).

10. Carta al P. Jerónimo Gracián, 14 de julio de 1581, 14.

11. Francisco Rivera, Vida de la Madre Teresa de Jesús, fundadora de las descalzas y descalzos carmelitas, libro II, capítulo 1, Madrid 2004, 195. 
Los rasgos más salientes de esta identificación como comunidad orante son, a nivel individual: vivir ante el Señor, en su presencia: «Los que tratan de oración están viendo que los mira», lo que se traduce en estar con el Señor y sentirlo cercano: «Si os acostumbráis a traerle cabe vos y él ve lo que hacéis con amor, no le podréis, como dicen, echar de vos, no os faltará para siempre, ayudaros ha en vuestros trabajos, tenerle heis en todas partes; ¿pensáis que es poco un tal amigo al lado?» (Camino 6, 1); tomar conciencia de su inhabitación, mirándolo dentro de sí: «No os pido más que le miréis» (Camino 26, 3); vivir la oración como amistad con Dios, «que sabemos nos ama», subrayando así la intimidad con el Dios amigo. A nivel comunitario: tener momentos fuertes de oración como son la Misa, las dos horas que la comunidad dedica cada día a la oración mental, el rezo de la liturgia de las horas, la lectura de textos espirituales. Introduce un matiz ambiental, la decoración de la casa, que se convierte en una llamada constante a la oración. Santa Teresa dice de sí misma que era amiga de hacer pintar la imagen del Señor en muchas partes. Ella da una gran importancia al uso pedagógico de la misma. La imagen no está para deleite estético, sino para entablar un diálogo con el Señor, para mover la devoción y fijar la memoria. Ella misma se lamenta de los que desestiman este recurso: «Bien parece que no aman al Señor, porque si le amaran, holgáranse de ver su retrato, como acá aún da contento ver el de quien se quiere bien» (Camino 9, 6).

La Madre Teresa está convencida de que es Dios quien reúne a las hermanas en comunidad, y por eso quiere monjas convencidas, vocacionadas, en sus casas -los «palomarcitos de la Virgen», como ella las denomina-, no que lleguen al convento para remediarse porque no encuentran su sitio en la sociedad.

Teresa trató de superar los grandes monasterios que se habían impuesto con la reforma de los Reyes católicos, las grandes comunidades, como era el de la Encarnación, donde ella habitó 27 años, caracterizado por ceremonias litúrgicas solemnes y hieráticas, una vivencia individualista de la relación con Dios y una notable falta de comunicación. El Carmelo nuevo, que ella inicia en una pequeña casa en San José de Ávila, se caracteriza por ser una pequeña comunidad de ambiente fraternal, el silencio y la soledad, alternándose con momentos de diálogo fraterno y espontánea comunicación -la recreación-. Buscó crear un grupo orante, insertado en el corazón de la Iglesia, a la que trata de ayudar con su oración. Para la Madre Teresa la oración es el cimiento de esta casa y a esto «nos juntamos», «es el ejercicio principal». Y respecto a qué tipo de oración, ella dirá: "Oración mental, y quien esta no pudiere, vocal y lección y coloquios con Dios»; «esto quiero yo, mis hermanas, que procuremos alcanzar, y no para gozar, sino para tener estas fuerzas para servir: deseemos y nos ocupemos en la oración»; «somos llamadas a la oración y a la contemplación».

La comunidad teresiana tiene sentido inserta en la Iglesia y a su servicio. Es una comunidad de intercesión, donde se ora por todos, en especial por las necesidades de la Iglesia. Su lucha por la Iglesia es el combate de la intercesión. Hay 
multitud de testimonios que recogen la realidad de este ideal. Súplicas por la Iglesia, por el Rey («en todo nos ha favorecido. Y así, hijas, os ruego yo mucho que siempre se haga particular oración por su Majestad como ahora la hacemos», Fundaciones 27,6), por los letrados y predicadores, por los obispos, religiosos y sacerdotes («todas ocupadas en oración por los que son defendedores de la Iglesia y predicadores y letrados que la defienden», Camino 1, 2), por los amigos y bienhechores, por la salvación de las almas. En este sentido el ideal teresiano se podría resumir en la frase vivir y orar por la Iglesia, y es que, como ella decía a sus monjas, «para esto os juntó aquí el Señor, este es vuestro llamamiento, estos han de ser vuestros negocios, estos han de ser vuestros deseos, aquí vuestras lágrimas, estas vuestras peticiones» (Camino 1,5).

Una vida dedicada a la oración, pero que no descuide el trabajo como fuente de sustento de la comunidad, ya que esta debe bastarse a sí misma, y más en comunidades que quieren vivir pobres y sin renta, aunque en este aspecto, como en otros muchos, evolucionará con el tiempo. Por esos las monjas deben ser aptas para trabajar. En las Constituciones establece que, aunque viven de limosna y sin renta, se ayuden "con la labor de sus manos», como hacía san Pablo. En Fundaciones pone como ejemplo de trabajo las tareas de la cocina, y es que para ella hasta «entre los pucheros anda el Señor». En el Modo de visitar los conventos establece que lo temporal-que antepone a lo espiritual «para que lo espiritual ande siempre en aumento»- es «importantísimo». Para la Madre Teresa hay que ser como Marta, «que si fueran todas como la Magdalena no hubiere quien diera de comer al Divino Huésped». «Pensad que es esta Congregación la casa de Santa Marta» (Camino 17, 5).

En cuanto al estilo de hermandad, Teresa señala la primera virtud que debe caracterizar a sus comunidades: «El amor de unas a otras» (1 Moradas 1, 17). Textualmente ella nos dice que: «En esta casa, que no son más de trece ni lo han de ser, aquí todas han de ser amigas, todas se han de amar, todas se han de querer, todas se han de ayudar» (Camino 4, 7). Teresa de Jesús pone el acento de la vida comunitaria en el retorno a la consigna evangélica del amor, como norma primera de vida.

Para mejor vivir el «amor de unas con otras», quiere que sus comunidades sean pequeñas: trece miembros en un principio; más tarde ampliará el número a veintiuna. El número tan pequeño de monjas se explica porque facilita la convivencia: «Adonde hay pocas, hay más conformidad y quietud» (Fundaciones 2, 1); las necesidades son menores: «Esto tengo por muchos pareceres sabido que conviene y visto por experiencia que para llevar el espíritu que se lleva y vivir de limosna y sin demanda, que no se sufre más» (Vida 36, 30); las desigualdades son menos notorias; el encerramiento más soportable, y pueden ayudarse mejor en el trabajo de sus manos. El número tan reducido de monjas lo utiliza la Madre Teresa como argumento para hacer ver que sus monasterios no son una carga para la sociedad. 
La comunidad teresiana -los palomarcicos de la Virgen- se define como un pequeño grupo de hermanas de la Orden de la Virgen del Monte Carmelo que, llamadas por el Señor, viven en pobreza, dejando en manos de Dios el cuidado de su mantenimiento, y que trabajan para ganarse el pan a ejemplo de san $\mathrm{Pa}$ blo, que dijo: «El que no quiera trabajar que no coma».

Para fortalecer el sentido de hermandad e igualdad -pues «todas han de ser iguales»-, la Madre Teresa suprime en sus comunidades todo aquello que pudiera constituir un atentado contra la igualdad comunitaria, el título de Doña, así como las diferencias sociales. De hecho, en la Descalcez, mientras vivió la Madre Teresa no se aceptaron los estatutos de limpieza de sangre. Para la Madre Teresa una condición importante para formar parte de sus comunidades es no tanto tener bienes de fortuna, sino ser persona de oración, tener buen entendimiento y estar desprendida del mundo y determinada a no quedarse en la mediocridad. Ya que la hermandad entre los miembros de la comunidad compromete a amarse fraternalmente sin excepción, toma como modelo a Jesucristo. Al margen del modelo de Jesucristo, la Madre Teresa da una razón muy humana para amarse, y es que el simple hecho de convivir debe hacer nacer la estima mutua y el amor entre las hermanas: «Tornando a amarnos unas a otras, parece cosa impertinente recomendarlo, porque ¿qué gente hay tan bruta que tratándose siempre y estando en compañía, y no habiendo de tener otras conversaciones, ni otro trato y creyendo las ama Dios y ellas a él que no cobre amor?» (Camino [Escorial] 7,7). Para fortalecer el igualitarismo comunitario recomienda, siguiendo el principio evangélico de «quien quiera entre vosotros ser el primero sea vuestro servidor», que «la tabla del barrer se comience desde la madre priora» (Constituciones 22), y pide que «la priora procure ser amada» (Constituciones 54 ).

La madre Teresa quiere monjas contentas, alegres en sus conventos, que sean capaces de compartir las alegrías, hablen con naturalidad. Ella, que no quiere "santos encapotados», decía en su Camino de Perfección al primitivo grupo de monjas de San José de Ávila: «Hermanas, todo lo que pudiereis sin ofensa de Dios procurad ser afables y entender de manera con todas las personas que os trataren, que amen vuestra conversación y deseen vuestra manera de vivir y tratar, y no se atemoricen y amedrenten de la virtud. A religiosas importa mucho esto: mientras más santas, más conversables con sus hermanas, y que aunque sintáis mucha pena si no van sus pláticas como vos las querríais hablar, nunca os extrañéis de ellas, si queréis aprovechar y ser amada. Que es lo que mucho hemos de procurar: ser afables y agradar y contentar a las personas que tratamos, en especial a nuestras hermanas» (Camino 41, 7).

La recreación es uno de los elementos que definen la vida del Carmelo fundado por la Madre Teresa de Jesús, la cual introdujo en sus comunidades dos horas diarias, por la mañana y por la tarde, de recreación. Y es que lo mismo que la religiosa dedica dos horas a Dios en la oración, dos horas ha de dedicar a las hermanas. Dos horas de distensión, alegría y comunicación entre las religiosas, 
lo que ayuda a acentuar el espíritu de hermandad que debe reinar en sus comunidades, y que, como la misma Madre afirma, sirve para «tomar un poco de alivio para llevar el rigor de la Regla» (Fundaciones 14, 5).

Otro elemento que define la vida de los carmelos teresianos, y que no siempre se resalta, es la cultura. Ella, que «siempre fue amiga de letras», decía que «es gran cosa letras, porque estas nos enseñan a los que poco sabemos», y estaba convencida de que «buen letrado nunca me engañó». Quiere en sus casas monjas con un cierto nivel de cultura religiosa, no se contenta con que sean solo devotas: «De devociones a bobas nos libre Dios». Por eso a las monjas les recomienda «informarse siempre de quien tenga buenas letras», y exige que la priora provea de «buenos libros» la casa, «porque es tan necesario este mantenimiento para el alma, como el comer para el cuerpo» (Constituciones 8). Incluso da una lista de los libros que no deben faltar en la biblioteca conventual: «En especial el Cartujano (la Vita Christi del cartujano Ludolfo de Sajonia), Flos Sanctorum, Contemptus mundi (la Imitación de Cristo), Oratorio de Religiosos (escrito por fray Antonio de Guevara y publicado en Valladolid en 1542), los de fray Luis de Granada y del padre fray Pedro de Alcántara» (Constituciones 8).

De este nuevo estilo de vida establecido por la madre Teresa hay que destacar un aspecto que afecta tanto a las personas como a las comunidades: la comunicación que promueve entre las distintas comunidades que ha ido fundando. Esto es lo que les da sentido de familia. Expresión de este espíritu es el continuo intercambio epistolar entre las comunidades, el envío de regalos y noticias de unas comunidades a otras, la mutua ayuda económica y el intercambio de religiosas que se estableció entre las comunidades. Todo esto, aunque la vida de las carmelitas es a «mayor encerramiento» y está centrada en la contemplación, ayudó a crear un auténtico sentido de hermandad y espíritu de familia, haciendo realidad lo que ella misma afirma: «Por eso traemos todas un hábito, porque nos ayudemos unas a otras, pues lo que es de una es de todas ${ }^{12}$.

\section{FUNDADORA DE FRAILES}

EI P. Francisco de Rivera, primer biógrafo de la Madre Teresa, reconoce que entre las grandes obras realizadas por la Madre está la fundación de los frailes, lo que califica de "cosa tan maravillosa y tan nueva en una mujer, y casi nunca vista desde el principio de la Iglesia acá» ${ }^{13}$.

En un principio, cuando funda San José de Ávila, no entraba entre los proyectos de la Madre Teresa la fundación de frailes, por eso a la pregunta ¿cuándo y por qué se decidió Teresa a fundar la rama masculina?, es ella misma la que nos dice que cuando estaba tranquila y contenta en su casa de San José, dedicada

12. Carta a la priora y hermanas del monasterio de Valladolid, 31 de mayo de 1579, 6.

13. Francisco Rivera, Vida de la Madre Teresa de Jesús, libro II, capítulo 7, 229. 
a la oración y a la vida fraterna, entre 1566 y 1567: «Cinco años después de la fundación de San José de Ávila, que me parece serán los más descansados de mi vida, cuyo sosiego y quietud echa harto menos muchas veces mi alma». Poco después de que a ella llegara la información sobre la situación de la Iglesia, que es el detonante que la conduce a la expansión de sus conventos de monjas y a la fundación de frailes. El motivo que la llevó a la fundación es la sensibilidad eclesial y apostólico-misionera de la Madre Teresa, que, frente a lo postulado por la mayor parte del movimiento protestante -la secularización del ministerio sacerdotal, el cerrar las iglesias o el remodelarlas en su interior, prescindiendo de las imágenes y del sagrario, el impedir la «devoción supersticiosa» de la gente-, ella toma conciencia de la necesidad de multiplicar los conventos de mujeres orantes, pero también de fundar de frailes, predicadores, misioneros que bautizasen a tantos indios como morían sin el bautismo, y contrarrestasen el avance protestante, sacerdotes que celebrasen la Misa y confesasen. Para Teresa las iglesias deben ser espacios abiertos y disponibles para las celebraciones litúrgicas comunitarias, la oración y la devoción personal, y donde encontrar sacerdotes que no solo celebren los actos litúrgicos, sino que además aliviasen las conciencias afligidas de los fieles a través de la confesión.

La idea de la fundación de los frailes partió de ella con la mediación del obispo Don Alvaro de Mendoza, quien aprovechando la visita a Ávila del General de la Orden, P. Juan Bautista Rubeo, pidió licencia «para que en su obispado se hiciesen algunos monasterios de frailes descalzos de la primera Regla. Él lo quisiera hacer, mas halló contradicción en la Orden; y así, por no alterar la provincia, lo dejó por entonces» (Fundaciones 2, 4).

Cuando en febrero de 1568 Teresa visita Duruelo, primera fundación de los descalzos, le gusta la faceta apostólica de predicadores que han adoptado desde los comienzos, pero no el «lugarcillo» donde han fundado, demasiado apartado para ella, que desea a sus frailes en los centros urbanos, y tampoco el exceso de penitencia, aunque los quería rigurosos, pero no en exceso, sino apostólicos, sacerdotes, predicadores.

La Madre Teresa proyectó su fundación de hombres como algo distinto, que no distante, a la de las monjas, resaltando entre las características de los frailes la preocupación eclesial y apostólica, no solo como preocupación, sino como servicio, acción y trabajo apostólicos.

Teresa, al contrario de lo que había sucedido con las monjas, no pudo controlar el desarrollo de los Descalzos, lo que llevará a que entre ellos se impusiese el rigor, la soledad, el apartamiento. Esto se debió, en buena parte, al crecimiento desorbitado que experimentaron los Descalzos a partir de Pastrana, fundado en 1569, donde predominará el espíritu eremítico-penitencial. Ella misma manifiesta cierto desencanto ante la evolución de sus Descalzos, al hablar de su encuentro con Jerónimo Gracián: «No he podido más, ni me ha parecido que se deje de hacer memoria de quien tanto bien ha hecho a esta renovación de la Regla primera. 
Porque, aunque no fue él el primero que la comenzó, vino a tiempo, que algunas veces me pesara de que se había comenzado, si no tuviera tan gran confianza de la misericordia de Dios. Digo las casas de los frailes, que las de las monjas, por su bondad, siempre hasta ahora han ido bien. Y las de los frailes no iban mal, mas llevaba principio de caer muy presto; porque, como no tenían provincia por sí, eran gobernados por los calzados. A los que pudieran gobernar, que era el padre fray Antonio de Jesús, el que lo comenzó, no le daban esa mano; ni tampoco tenían Constituciones dadas por nuestro reverendísimo padre general. En cada casa hacían como les parecía. Hasta que vinieran, o se gobernaran ellos mismos, hubiera harto trabajo, porque a unos les parecía uno y a otros otro. Harto fatigada me tenían algunas veces» (Fundaciones 23, 7).

\section{CONCLUSIÓN}

Estando en Palencia la Madre Teresa, recibe una grata noticia: la separación de los Descalzos de los Calzados, con lo cual ve que su obra fundadora -22 conventos, con cerca de trescientos frailes y doscientas monjas- no solo está cumplida, sino que tiene continuidad: «Y me dio a mí uno de los grandes gozos y contentos que podía recibir en esta vida... Ahora estamos todos en paz: Calzados y Descalzos, no nos estorba nadie a servir a Nuestro Señor» (Fundaciones $29,31)$. La Madre Teresa, está contenta con la obra que había comenzado quince años atrás, aunque no siempre las cosas evolucionaron como ella deseaba, sobre todo en lo que respecta a los frailes. Un mes antes, a finales de marzo de 1581, había escrito a María de San José, la priora de Sevilla: «Ahora, mi hija, puedo decir lo que el santo Simeón, pues he visto en la Orden de la Virgen Nuestra Señora lo que deseaba; y así, les pido y les ruego no rueguen ni pidan mi vida, sino que me vaya a descansar, pues ya no les soy de provecho». 